\title{
A MODEL FOR COASTAL TOURISM: THE COAST IS ALL IN ONE'S MIND
}

\author{
MARTIJN SMEENGE and BEN OFFRINGA \\ Professorship in Visitor Studies, NHTV Breda University of Applied Sciences, Breda, The Netherlands
}

\begin{abstract}
Globally, coastal areas can be seen as the most popular tourist-recreational destinations. Consequently, these destinations generate major visitor flows. Furthermore, they are interpreted differently by every visitor, for example depending on lifestyles and age. These two problems, or maybe chances, are the central focus in this article. More specifically, this conceptual paper examines what the typical coastal experience consists of and in which ways the producers of the tourist-recreational coastal product can anticipate this. After explaining the principles of visitor management, as defined by Ennen, a theoretical framework is presented that tries to capture the total coastal experience. Then, two existing coastal areas are projected onto this framework. Finally, some conclusions are drawn.
\end{abstract}

Key words: Coastal tourism; Visitors; (Re)Interpretation

\section{Introduction}

Globally, coastal areas can be seen as the most popular tourist recreational destinations. Consequently, these destinations generate major visitor flows (Smeenge, 2008). Furthermore, these destinations are interpreted differently by every visitor, for example depending on lifestyles, age, personal preferences, and so on. These two problems, or maybe chances, are the central focus in this article.

Within the associate professorship in Visitor Studies, visitor management is defined as the striving for balance between the visitor, the destination, and the users (including residents) of the destination (Ennen, 2006, 2007). It is introduced here as a strategy to generate and manage desired effects of visitor flows and it sets forth the elements that make up the discipline of visitor management, analyzing the variables of "connection," "experience," and "enticement" of visitors and users.

As a result, this conceptual article examines what the typical coastal experience consists of and in which ways the producers of the tourist-recreational coastal product can anticipate this. More specifically, this article tries to give some insights into the coastal concept or mindset of users and visitors in particular.

After explaining the principles of visitor management, a theoretical framework is presented that tries to capture the total coastal experience. After this, two existing coastal areas are projected onto this framework, namely Zeeland, (a coastal prov- 
ince in the Netherlands), and the Canadian coastal town of Tofino. Finally, some conclusions are drawn.

\section{Visitor Management}

Central to the domain of visitor management are visitor flows. Visitor flows can be analyzed quantitatively as well as qualitatively. In terms of quantity, one might think of a situation where a destination has (too) many, enough, or (too) few visitors. Quality, on the other hand, involves desired and/or undesired effects resulting from visitor flows (see Fig. 1).

Different situations call for different management approaches, depending on the effects they bring about. For instance, too many undesired visitors at a destination can cause negative effects, such as traffic inconvenience and noise nuisance for residents, or damage to objects and sites that are of major significance. Too few desired visitors put the economic viability of a destination at risk, whereas too many desired visitors may indeed be attractive to a destination from an economic point of view, these visitor numbers may also generate negative effects of a social-psychological nature for local users such as residents.

Ennen (2007) has defined visitor management as "striving for balance between the destination, the visitor and the user" (p. 3) (see Fig. 2). A destination can be anything. It may be a historical city center, a theme park, a heritage site, an airport, an attraction, a shopping centre or, in this case, a coastal area. These are all environments where visitor flows are managed or generated for various pur-

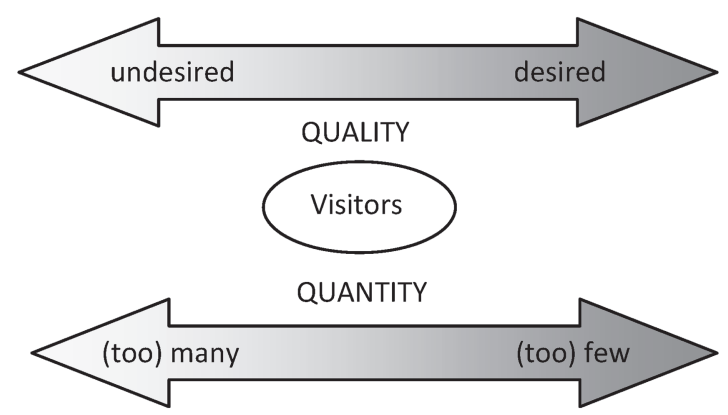

Figure 1. Visitors: Quantitative and qualitative approach. Source: Associate Professorship in Visitor Studies (2008).

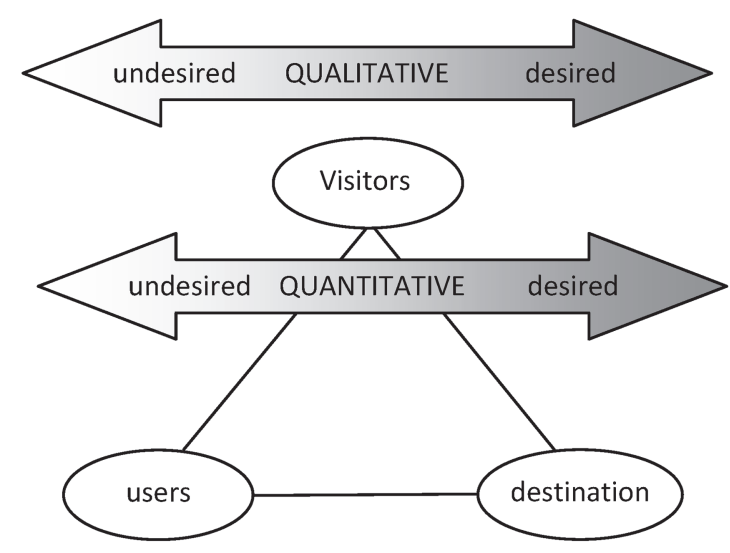

Figure 2. Balance between destination, visitor and user. Source: Associate Professorship in Visitor Studies (2008).

poses. Users include both residents and other parties involved, such as businesses, government, institutions, and organizations. The degree to which balance is achieved is of major importance to the quality of the destination.

The Professorship in Visitor Studies at NHTV Breda University analyzes the role of the variables of connection, experience, and enticement of visitors (see also Ennen 2006, 2007). The variable of connection involves research questions such as: Who are (desired) visitors of the destination concerned? What are their preferences; to what degree do visitors feel connected to a destination? and How do destinations contribute to social cohesion in people's everyday lives?

The second variable, experience, is about research questions such as the factors that contribute to a positive experience of the destination and where the turning point lays that changes the experience from positive to negative. Enticement, in conclusion, is the resultant of connection and experience. A sound analysis of the connection and experience of visitors will elucidate how visitors can be enticed to make certain (different) choices or decisions. Enticement, in its turn, is obviously influential to the degree of connection and experience that a destination inspires in visitors.

\section{Coastal Model}

One of the results produced by the exploratory study "Coastal Tourism: A Tour d'Horizon" 
(Smeenge, 2008) was a new theoretical framework for coastal tourism. This transformational model of the coast involved a continuous and dynamic process that should, by no means, be regarded as a preconceived step-by-step plan that can be followed neatly from top to bottom. In fact, it was constructed to give insights into the factors that play a role in the process of coastal resources transforming into tourist recreational products. Here, this theoretical framework has been updated in such a way that it represents an even more process-oriented view (see Fig. 3).

This model represents the continuous process of transformation of coastal resources by all stakeholders (producers and consumers) into a commercial tourism recreational product (Dietvorst, 1992; Jansen-Verbeke, 1988). In other words, there are numerous possibilities to select resources and to transform them into desired products. Resources can be anything, such as different natural environments, (historical) stories, objects, and, of course, coastal areas. By making a selection from these resources, they are in fact interpreted in such a manner that a product emerges. Consumers, however, also give meaning to the resources, depending on their lifestyle, wishes, and overall family and financial situation. The meaning they attach to the resources is what determines the tourist recreational value in the end. This attached meaning largely depends on how people are connected to the resource, how they experience the resource, and how they are enticed to visit the resource (the triangle of three variables in the center of the model). It is precisely this step that is so important, but overlooked too often.

In this process of transformation or commodification (Ashworth \& Tunbridge, 1990), it is mostly just the material or tangible component that is considered, for instance, the construction of new facilities. The other component, immaterial or intangible transformation, is probably much more important. As soon as producers attach a certain tourist-recreational meaning to resources or manipulate these resources (encoding), and consumers also (re)interpret these resources, as such (in the most favorable case, and with or without the help of the media), these resources will actually assume value in terms of tourism and recreation. A story or experience value is added to the resources, so to speak.

\section{Coastal Concept}

In order to give further direction to the research program "Visitors and the Coast" within the Asso-

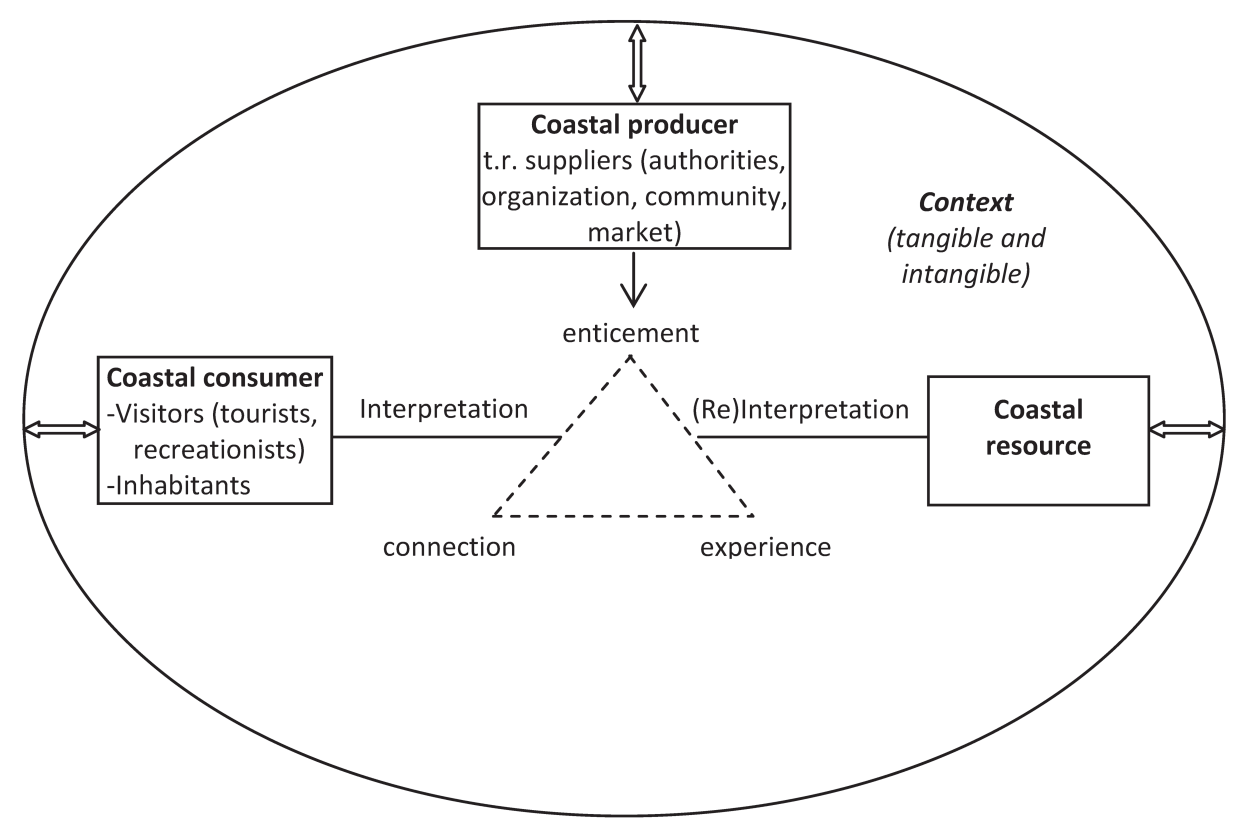

Figure 3. Coastal model. 
ciate Professorship in Visitor Studies, the authors decided to focus on two perspectives, namely mental image and physical environment of the coast (see Fig. 4). From a mental image point of view, the coast is seen through the eyes of the visitor/user, or in other words, the coast is all in one's mind. Every single person has his own thoughts, images, and expectations of the coast, often depending on past experience or obtained information. In this case, you can also speak of a coastal concept or a coastal mindset. In fact, this is rather a more psychological and sociological perspective and the main perspective of this article.

The second viewpoint, about physical environment, discusses the coast from the perspective of the destination. In concrete terms, here can be the thought of comparisons of coastal destinations from a historical perspective in the past and/or present. For instance, the way(s) a coastal destination has developed through time or the way(s) the development of one coastal destination differs from another one.

Throughout both perspectives mentioned above, the issue of storylines takes a central place. Storylines can be characterized in two different ways. One type of storyline is a consistent narrative or image that is typical for a region and among other things, therefore, can be used as a marketing instrument (Moes, 2008). The ultimate goal of a storyline is to create spatial quality and a different perspective on regional development in order to inspire tourist recreational product development. It is about bringing about a dynamic combination between past and present and regional identity and econom-

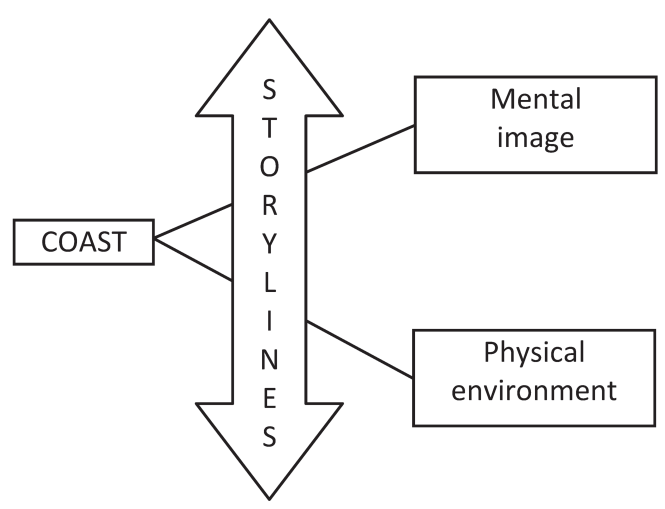

Figure 4. Coastal interpretation. ic mobility in such a way that synergetic effects will occur (Vromraad, 2006). The second type of storyline is a narrative which is formed within the mind of the visitor of the coast. It is based on past experiences, on stories told by other people, and on information gathered through the media. It informs the visitor, thereby enabling him/her to be making a choice of destination or activity. It can be shared with other people, forming some kind of community.

In this article, the first perspective, the mental image of the coast, is emphasized. Thus, the coast can be experienced in the mind as a set of elements, which can be recalled at will even if the person is situated far away from the coastline. This mindset consists of loose components, which the person attaches a meaning to and arranges them in such a way as to be meaningful to him. This is more or less comparable to the idea of "tourismscapes" (van der Duim, 2007). The relations between the components are given meaning by organizing them in one or more storylines. As is said before, a memory of the timeline of a day visiting the beach can be such a storyline. Another one could be thinking about the best waves for surfing that a person experienced (or heard about).

In a small $(n=15)$ experiment in two workshops for employees of NHTV Breda University of Applied Sciences (January 2009), the authors initiated a research by trying to capture the coastal concept. In these workshops, they introduced the participants to some basic information about coastal tourism and our research program. After this, the authors asked them to come up with any thoughts, images, connotations, or whatsoever they had on coastal destinations in general. It was apparent that the participants could easily evoke beach images and memories, even if the setting was a dull lecture room without any stimulus at all. Participants could describe sights, sounds, and smells of the beach, often originating from early childhood experiences. One person told that she, at that very moment, actually smelled the sea! The recollection evoked the sensation.

With the help of the computer program "Mindjet Mindmanager," the authors wrote down everything that was mentioned. Subsequently, the obtained data were clustered. As can be seen in Figure 5, the results show a great variety in coastal connotations. 


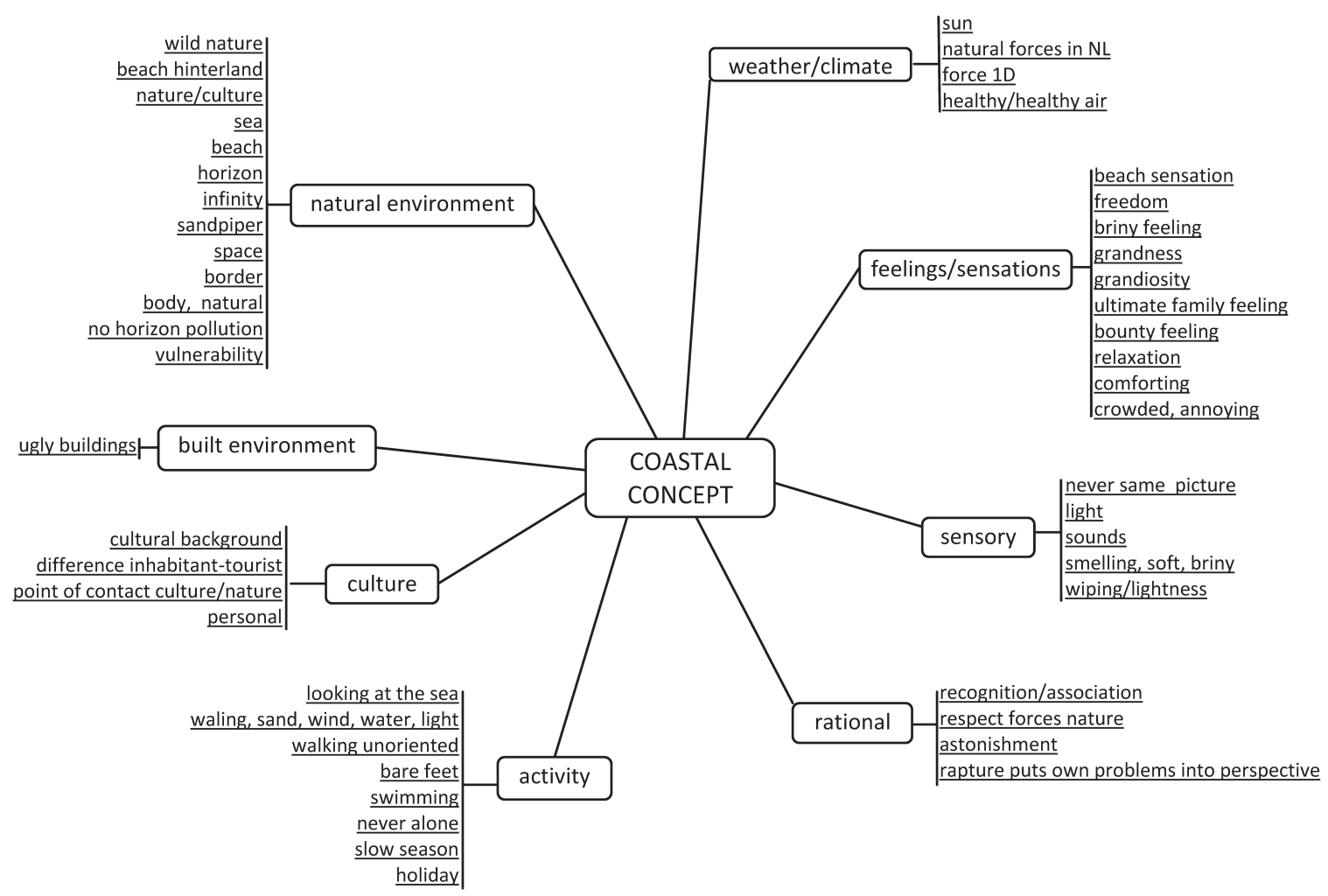

Figure 5. Mindmap of coastal concept.

A few things can, with caution, be concluded from this (admittedly not scientific) experiment. Firstly, it appears that beach memories recollect a very strong experience and have entered long-term memory (Larsen, 2007). Perhaps this is because it often originates from childhood, in which new impressions settle easily in the brain. Perhaps this is also the case because a beach experience, with its vast expanses of water and sand, and its roaring sounds of the waves, is quite an experience for a small child (Lencek \& Bosker, 1998).

A mental image can be very important in choosing a destination. It feeds into the expectations before a trip, it colors the actual experience, and it helps to position new experiences relative to the old experiences into the mindset in order to create enhanced memories (Larsen, 2007). This is subject to the fulfillment of a person's needs. If the mental image of the beach can be fulfilled in other ways than actually visiting a beach itself (e.g., by going to Tropical Islands near Berlin or city beaches) it can have important implications for redirecting visitor flows to the coast on warm, sunny days.

Of course the image of the beach was different for every person who participated in the small experiment, mentioned above. Every person had other things to tell. "There are many different types of tourist out there" (O’Dell, 2007).

The second viewpoint is the one most commonly known: actually visiting the site itself by "being, doing, touching and seeing" (Crouch \& Desforges, 2003). The (beach/coastal) destination tells a story. It is a stage set ready for enacting scripts (Baerenholt, Haldrup, Larsen, \& Urry, 2004). This is all about branding, marketing, and segmenting the beach. Particularly useful is the concept of "servicescapes" or "constructed physical surroundings intended as sites in which commercial exchanges are to take place and include ambient, social and design factors" (Bitner, 1992; Mossberg, 2007).

The concept of servicescape is often used in relation to retail stores or hotels (Mossberg, 2007). It 
can also be applied to coastal resorts or beach environments in which stakeholders are working together to get a message across.

Sleeping on the Beach, Zeeland, The Netherlands

The relatively small province of Zeeland (area of 293,389 hectares, about 380,000 inhabitants in 2008) (Kenniscentrum Toerisme \& Recreatie, 2008; www.statline.cbs.nl) is one of the oldest and traditional seaside resorts of the Netherlands, located in the Southwest of the country, along the North Sea. It has got a coastal strip of $600 \mathrm{~km}$ (www.zeeland. $\mathrm{nl}$ ). In the whole province, tourism is of major importance for the local and regional economy. In 2007, a total of 2,023,000 guests visited Zeeland, of whom 1,321,000 guests were domestic visitors and 702,300 were foreigners. Furthermore, Zeeland had, in the same, year a total of $11,584,300$ overnight stays, of which $8,055,000$ were domestic and $3,529,300$ were foreign. This means that approximately seven percent of the total guests in the Netherlands in 2007 visited Zeeland, and a good 9\% of the total overnight stays took place in Zeeland (Kenniscentrum Toerisme \& Recreatie, 2008).

In Zeeland, tourism businesses generally are very small, diverse, and fragmented (ZKA, FABRIC, $\&$ Telos., 2008). In most cases these businesses are just small family businesses, and the owner is only worried about/attached to his or her own business. As a result, the potential to invest of most tourist recreational businesses is relatively low, which in turn has consequences for their innovation capacity. In order to overcome these problems, local and regional authorities are trying to combine forces and point everyone in the same direction in order to create a universal image/story of Zeeland. An initial impetus has been given in the form of the report Terug naar de Kust ("Back to the Coast") (ZKA, FABRIC, \& Telos, 2008), which must give content to a broader storyline (see also the previous paragraph) that captures and connects all the unique selling points (USPs) of the Zeeland region.

A few years ago, a number of holiday cottages were built and placed on several beaches in Zeeland, for instance on beaches nearby the towns of Vlissingen and Domburg (see Fig. 6). Because of legislation, these cottages have to be removable, and therefore they are only to be found on the beaches between the months April and October (www.slapenopstrand.nl; www.slaapstrandhuisje.nl). This does not automatically mean that these cottages have very basic equipment. In fact, just as any other holiday cottage, every single cottage has got a luxury kitchen, bathroom, toilet, television, terrace, and so on. What makes these cottages so special for the Netherlands is of course their location: the beach.

These holiday beach cottages can be seen as an illustration of the model the authors introduced earlier this article. Starting with the producers, they use the resource (the beach) to create a servicescape. The beach is seen as a marginal place in which the everyday realities for the time being can be ignored. It is a place where everybody can play and do things you normally would not dream of doing (Ryan, 2002). The producers expand this notion of marginality to encode it to offer a unique way of staying the night in a traditional seaside resort. In this, they create a story which the tourists could actually experience (e.g., sleeping on the beach, looking at the sea).

In this, possibly kindling the childhood memory of past seaside experiences or mindset by playing on the beach (e.g., building sandcastles, searching for shells, playing Frisbee, running through the sea) and perhaps fantasizing about staying the night as close as possible to the sea. It has been shown how strong these memories can be. A night on the beach, for some, surely must be a dream come true. Imagine yourself waking up in the morning, opening the door of your cottage and stepping out in your swimming gear, directly on the beach into the sea! To whom does this not sound appealing? And therefore the producers enticed their audience by making this a real possibility.

Most consumers probably knew about Zeeland as a traditional seaside destination. It is one of the first of the kind in the Netherlands and is well known in the country. The consumers interpret the resource (the beach and the Zeeland region); they also interpret the story of the real-life holiday beach cottages being encoded for them by the producers. Some of the consumers will find this interesting; they make a connection with it. A few will take the step of actually coming to Zeeland and staying there in one of the cottages mainly because of this.

Thus, for some of the consumers, it sets Zeeland 


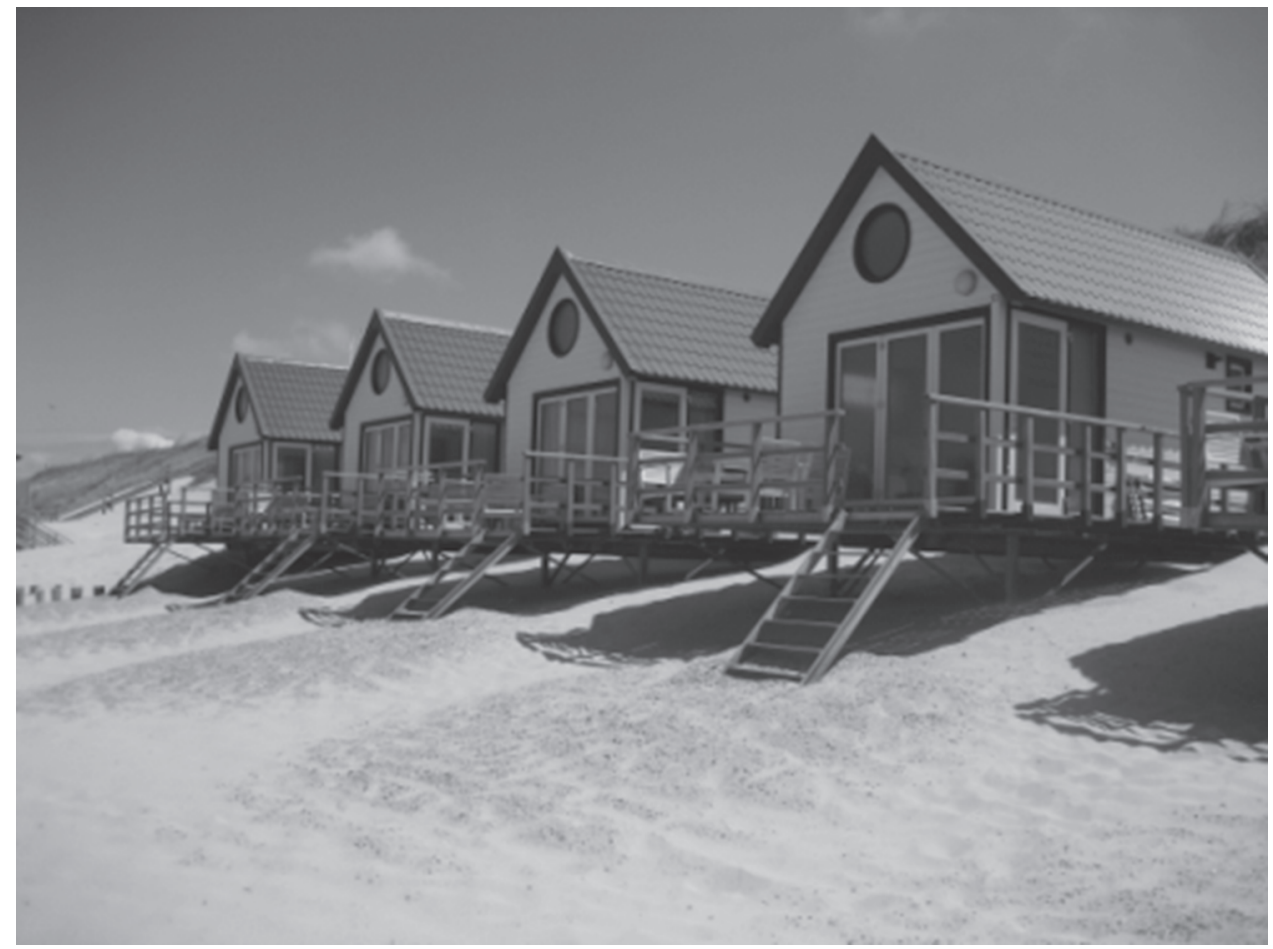

Figure 6. Holiday beach cottages in Domburg, Zeeland, the Netherlands (photo by M. Smeenge).

in a different light. Not as a traditional seaside resort, but as something special. Staying in a traditional bed-and-breakfast in Zeeland does not make you popular at birthday parties back home, but staying the night at the beach, with all its unique features, surely is a tale to tell.

The media are playing a central role in getting the enticement (which was fabricated by the producers, using and expanding the resource by building the cottages), to the audience. Media can be the traditional ones in the form of newspapers, radio, and television. But social websites like Facebook, Flicker, and Twitter (web 2.0) are increasingly important in getting the message across. In this, they facilitate the audience to get connected to the story.

The general context here is the decline in popularity of the traditional seaside resorts in Zeeland in the last decennia (although in the last years visitor numbers have increased again, see also the beginning of this section) and the way in which these seaside resorts are trying to counter this. When there is a slight increase in popularity, noted seaside resorts have to get on the "band-wagon" in or- der to secure a slice of the cake. In this, they have to "stand out of a crowd." so to speak. The holiday beach cottages are a sure way of doing this.

\section{Tofino, Canada: Watching the Waves}

On the west coast of Canada, only a few places are accessible for tourists. One of these places is Tofino, a town of about 1,700 inhabitants on Vancouver Island. The town was once a small fishing port, but there also was a lot of logging in the vicinity.

In the 1970s, tourism was introduced in Tofino. It started as a small surfer resort, but changed to a year-round more up-market tourism destination (Gill \& Welk, 2007). This change is an interesting one, as it is useful as an illustration of the model introduced above.

The resource used here is the rugged coastline with a lot of inlets, small islands, and beaches. It has great surf because a large part of this coastline lies exposed to the ocean. Previously, the surf was used only in summer by the surfing community. The stormy winter months were quiet, until in the 
mid-1990s, when luxury accommodation was built with a direct view of the Pacific Ocean.

One of the producers, the newly built Wickaninnish Inn (www.wickinn.com), introduced storm watching as a new commodified product to fill the quiet winter months. As so often is the case, this was not the result of shrewd marketing plan, but discovered more or less by accident. The owners of the inn, the McDiarmid-family, used to have a cabin in the area. Whenever a winter storm was about, the kids went outside to watch the breakers and totally forgot to watch television. This notion got stuck with the present owner and manager, Charles McDiarmid. In 1996, the inn was built with every hotel room, as well as the lobby and restaurant, supplied with a view of the ocean. So the inn, by creating a servicescape, encoded the resource for use by the customers. It even went as far as making it possible to watch a storm from the bathtub in the room.

Of course, the media publicized this widely (e.g., "Wenn Sich Kein," 1999; Warwick, 1998). This attracted the attention of lots of visitors not only from Canada, but also from the US and even from Europe. They, the customers, interpreted this as an opportunity to enjoy the force of nature, without being in any personal danger at all. No rain or hail in your face, no wind to stand up against. Just watching the fierce breakers from the warm and cozy atmosphere of the hotel, perhaps with a drink within reach.

So, this is a possibility to experience nature at its fiercest, with the enticement of doing this from your hotel room, thus, without leaving your comfort zone. Nature watching is now possible not only for the rugged nature freak, but also for the weakhearted city dweller. Thus, this commodification of the coast makes a connection with a new audience, enlarging the population interested in coming to Tofino.

\section{Conclusion}

Within a given context, the model presented above can be used to analyze some of the ways in which a coastal destination can mark its way into the customers' minds. In order to successfully entice the customer to a coastal destination, it is important to have a clear idea of the coastal mindset(s) of the visitor and the stories in which they organize the components of this mindset(s).

The coastal producers use the resource (the beach, the resort) and the media to reach out to the customers. In the case of Zeeland, the beach cottages are an instrumental servicescape to counteract the decline in popularity of the resorts in this destination. They play into the (youth) memories of people in facilitating a perhaps once held dream: sleeping on the beach.

In the case of Tofino, the possibility of securing a new market was shown by opening up the force of nature to audiences who would not otherwise dream of coming. Experiencing the big breakers on the shore was once an experience for the rugged. Now it can be enjoyed in luxury. Based on their coastal mindsets, the customer interprets if what is being offered connects with their coastal concept. If so, they probably experience it accordingly to the mutual benefit of producer and visitor. The ideal situation is reached when a balance is created between the destination, the visitors, and the users by using the tools; enticement, connection, and experience.

Finally, it has to be emphasized that this research still is work in progress. With the first results of the small mind mapping experiment mentioned earlier, the authors actually just have started. In the future, they hope to make more contributions to this topic and also to be able to present more scientifically valid results.

\section{Ubuntu in Action}

A lot of tourism destinations are in danger of becoming obsolete, particular coastal destinations. They have to reinvent themselves in order to stay tuned to the ever changing coastal tourism market. A surprising few do this, by actually listening to and learning from their visitors. Visitor management, as understood in this article, is meant to be a cocreation between the producers at the destination and the consumers who visit it, both using the coastal resource in order to reframe and encode it. Storytelling is central. The producers tell a story, thereby setting the destination in a certain light, which they hope will attract customers. Consumers attracted by this story want to experience this.

Consumers do certainly have a stake in a coastal 
destination. They want to have a good time, but they also take home memories. Consequently, the stories people tell at home as an expression of these memories about their actual experiences at the destination can be a very useful resource in establishing the things they have valued most in their visit. This enables the producers to play even better into the hands of the customers. The authors hope this article serves to indicate to the people responsible at the coastal destinations, to stay in line to the market by actually learning from the experience of the consumers.

\section{Biographical Notes}

Martijn Smeenge is Lecturer/Researcher at NHTV Breda University of Applied Sciences, NL, with special interest in coastal tourism and wellness. He is member of the Professorship in Visitor Studies. He is also lecturer at HZ University of Applied Sciences in Vlissingen, NL, where he is affiliated to the Research Centre for Coastal Tourism.

Ben Offringa is Senior Lecturer at NHTV Breda University of Applied Sciences in Breda, NL. Currently he lectures in Coastal Tourism, Destination Marketing, Tourism Geography, and Travel Writing.

\section{References}

Ashworth, G.J. \& Tunbridge, J.E. (1990). The Touristhistoric City. London: Belhaven.

Baerenholt, J.O., Haldrup, M., Larsen, J., \& Urry, J. (2004). Performing Tourist Places. Aldershot [etc.]: Ashgate.

Bitner, M. (1992). Servicescapes: The Impact of Physical Surroundings on Customers and Employees. Journal of Marketing 56(4), 57-71.

Crouch, D., \& Desforges, L. (2003). The Sensuous in the Tourist Encounter. Tourist Studies 3(1), 5-22.

Dietvorst, A.G. (1992). Een model van toeristisch-recreatieve productontwikkeling. Vrijetijd en Samenleving, $10(2 / 3), 21-28$.

Ennen, E. (2006). Bindingen, belevingen en verleidingen. Bewegingen in onderzoek binnen het domein van Visitor Management. Breda: NHTV/Academic Studies 3.

Ennen, E. (2007). Dilemma's in bezoekersstromenland. Wat gaan we (nu weer) beleven? Breda: NHTV/Academic Essays 1.

Gill, A., \& Welk, E. (2007). Natural heritage as place identity: Tofino, Canada, a coastal resort on the periphery. In S. Agarwal \& G. Shaw (Eds.), Managing coastal tourism resorts - a global perspective (pp. 169-183). Clevedon: Channel View Publications.

Jansen-Verbeke, M. (1988). Leisure, recreation and tourism in inner cities: Explorative case studies. Nijmegen: Katholieke Universiteit Nijmegen, Geografisch en Planologisch Instituut.

Kenniscentrum Toerisme \& Recreatie. (2008). Toeristische Trendrapportage Zeeland 2007/08. Vlissingen: Hogeschool Zeeland, Kenniscentrum Toerisme \& Recreatie.

Larsen, S. (2007). Aspects of a psychology of the tourist experience. Scandinavian Journal of Hospitality and Tourism; 7(1), 7-18.

Lencek, L., \& Bosker G. (1998). The beach, a history of paradise on earth. London: Secker and Warburg.

Moes, W. S. (2008). Werk maken van regionale beeldverhalen: toerisme in Nederland krijgt een nieuw en duurzaam profiel. Den Haag: Raad voor ruimtelijk, milieu- en natuuronderzoek (RMNO).

Mossberg, L. (2007). Extraordinary Experiences through Storytelling. Scandinavian Journal of Hospitality and Tourism; 7(1), 195-210.

O'Dell, T. (2007). Tourist experiences and academic junctures. Scandinavian Journal of Hospitality and Tourism; $7(1), 34-45$.

Ryan, C. (2002). The tourist experience. London/New York: Continuum.

Smeenge, M. (2008). Kusttoerisme: een tour d' horizonEen inventarisatie van het domein kusttoerisme. Breda: NHTV Expertise Series 1

van der Duim, R. (2005). Tourismscapes, an Actor-Network Perspective. Annals of Tourism Research 34(4), 961976.

Vromraad (2006). Groeten uit Holland, qui è fantastico! Advies over vrije tijd, toerisme en ruimtelijke kwaliteit. Den Haag: OBT bv.

Warwick, H. (1998, July 25). Back on dry land. The Times Weekend.

Wenn sich kein Lüftgen rägt . . . . (1999, September 3. Süddeutsche Zeitung Magazin.

ZKA, FABRIC \& Telos (2008). Terug naar de Kust. Nieuwe marktallianties voor toeristische gebiedsontwikkeling in de Delta. Roosendaal: SES West-Brabant. 